\title{
Isolation and Characterization of Escherichia coli Clones Expressing Cellulase Genes from Cellulomonas fimi
}

\author{
By N. R. GILKES, D. G. KILBURN, M. L. LANGSFORD, \\ R. C. MILLER, JR, *W. W. WAKARCHUK, R. A. J. WARREN, \\ D. J. WHITTLE AND W. K. R. WONG \\ Department of Microbiology, University of British Columbia, Vancouver, British Columbia, \\ Canada V6T 1W5
}

(Received 13 October 1983; revised 20 January 1984)

\begin{abstract}
A sensitive immunoassay developed previously was used to isolate a series of Escherichia coli clones expressing cellulase genes from Cellulomonas fimi. The clones fell into three groups. Clones in the first group contained plasmids with a $6.6 \mathrm{~kb}$ insert of $C$. fimi DNA, were strongly antigenic, and contained low levels of CM-cellulase activity. Those in the second group contained plasmids with a $5.0 \mathrm{~kb}$ insert, were weakly antigenic, and contained high levels of CM-cellulase activity. Those in the third group contained plasmids with a $5.6 \mathrm{~kb}$ insert, were weakly antigenic, and contained low levels of CM-cellulase activity. Restriction analysis showed that the three groups carried different cellulase genes. All of these CM-cellulase activities were exported to the periplasm in $E$. coli, but with different efficiencies. These activities represented important components of the $C$. fimi cellulase complex. Their properties indicated that they were different from each other and that they probably had complementary actions.
\end{abstract}

\section{INTRODUCTION}

Cloning appropriate structural genes is one approach to increasing cellulase production. We are attempting to clone the genes determining the components of the cellulase system of Cellulomonas fimi into Escherichia coli. To facilitate screening, we developed a simple, sensitive immunoassay for the detection of recombinant plasmids carrying cellulase genes from $C$. fimi. The assay was used to isolate a recombinant plasmid which directs the synthesis in $E$. coli of detectable levels of cellulase activity (Whittle et al., 1982). We report here on the identification and characterization of additional clones expressing our previously reported activity as well as two new classes of clones producing different components of the $C$. fimi cellulase system.

\section{METHODS}

Bacterial strains and media. Except for E. coli CSR603, the bacterial strains and the media used for their cultivation were described previously (Whittle et al., 1982). Escherichia coli CSR603 was the strain used to identify plasmid-coded proteins by the maxi-cell method (Sancar et al., 1979).

$D N A$. The isolation of chromosomal DNA from $C$. fimi and of plasmid DNA from E. coli, digestion of DNAs with restriction endonuclease $B a m H I$, cloning of fragments of $C$. fimi DNA into pBR322, and the transformation of $E$. coli were described previously (Whittle et al., 1982). Restriction digests of DNAs were fractionated by agarose gel electrophoresis (Dunn et al., 1979); and plasmid DNA was isolated by the alkaline lysis procedure (Maniatis et al., 1982).

Screening of recombinant clones for cellulases. The procedures for the selection of recombinant plasmids and their immunological screening for cellulase were described previously (Whittle et al., 1982).

Enzyme assays. Cellulase activity was measured colorimetrically (Miller, 1959) using CM-cellulose as substrate (Miller et al., 1960). One unit of enzyme released $1 \mu \mathrm{g}$ glucose equivalents $\min ^{-1}$ as determined by reference to a standard curve. $\beta$-Lactamase activity was measured with nitrocefin as the substrate (O'Callaghan et al., 1972). $\beta$-Galactosidase activity was measured with $o$-nitrophenyl- $\beta$-D-galactoside as the substrate (Miller, 1972). 
PAGE. The procedures used for PAGE of proteins are described in the accompanying paper (Langsford et al., 1984).

Analysis of cells for the location of CM-cellulase activity. Total cell extracts were prepared by rupturing the cells with a French press (Whittle et al., 1982). Periplasmic proteins were obtained from spheroplasts by osmotic shock (Neu \& Heppel, 1965; Nossal \& Heppel, 1966). Zones of hydrolysis around colonies on CM-cellulose plates were detected with Congo red (Teather \& Wood, 1982).

Identification of plasmid-coded proteins. Plasmid-coded proteins were identified by the maxi-cell technique (Sancar et al., 1979), after transformation of E. coli CSR603 with the appropriate plasmid.

Enzymes and reagents. Enzymes were purchased from New England Biolabs, and ${ }^{125}$ I-labelled protein A was prepared as described previously (Whittle et al., 1982).

\section{RESULTS}

Isolation of further clones determining cellulase activity

The first plasmid obtained, pDW1, contained a $20 \cdot 2 \mathrm{~kb}$ insert from a partial BamHI digest of C. fimi DNA. Exhaustive digestion of pDW1 with BamHI released $1.6,6.6$ and $12.0 \mathrm{~kb}$ fragments of $C$. fimi DNA (Whittle et al., 1982).

The DNA from a total BamHI digest of $\mathrm{pDW} 1$ was used to construct recombinant plasmids from pBR322. Those recombinants determining cellulase activity were detected by immunoassay of ampicillin-resistant, tetracycline-sensitive clones (Whittle et al., 1982). All fifteen of the positive clones which were screened contained a $6.6 \mathrm{~kb}$ insert of $C$. fimi DNA (data not shown). This prompted us to attempt the cloning of further cellulase genes from total rather than partial BamHI digests of C. fimi DNA.

Sixty-one immunopositive clones were obtained from 6500 ampicillin-resistant, tetracyclinesensitive clones; 38 of these exhibited cellulase activity. The cellulase-producing clones fell into three groups on the basis of antigenicity (as judged from the screening autoradiograms) and cellulase activity. One group (five clones) was strongly antigenic but gave low levels of enzyme activity; the second group (eight clones) was weakly antigenic but gave high levels of enzyme activity; the third group ( 25 clones) was weakly antigenic and gave very low levels of enzyme activity.

All of the clones in the first group contained a plasmid, designated $\mathrm{pECl}$, with a $6.6 \mathrm{~kb}$ insert of $C$. fimi DNA (Fig. 1). All those in the second group contained a plasmid, designated pEC2, with a $5.0 \mathrm{~kb}$ insert of $C$. fimi DNA (Fig. 1). The screening of the remaining clones is incomplete; of the 10 screened thus far, the plasmid in three of these, designated pEC3, contained a $5.6 \mathrm{~kb}$ insert of $C$. fimi DNA (Fig. 1). The $6.6 \mathrm{~kb}$ insert in pEC1 was identical to the cellulase-encoding insert in $\mathrm{pDW} 1$.

\section{Comparison of $p E C 1, p E C 2$, and $p E C 3$}

The $C$. fimi inserts in $\mathrm{pEC} 1, \mathrm{pEC} 2$ and $\mathrm{pEC} 3$ gave different restriction patterns with $S a l I$ and PstI (Fig. 2). Cell-free extracts from cells carrying these plasmids gave single bands of CMcellulase activity by non-denaturing PAGE (Fig. 3). Therefore, the genes encoding the enzymes were clearly different, but the enzyme mobilities in PAGE were very similar. They compared closely to the substrate-bound enzymes seen in normal C. fimi supernatants (Langsford et al., 1984).

\section{Polypeptides determined by pEC plasmids}

Escherichia coli CSR603(pEC) strains were prepared by transformation with $\mathrm{pEC1}$ and $\mathrm{pEC} 2$. Plasmid-determined polypeptides were labelled with $\left.{ }^{35} \mathrm{~S}\right]$ methionine after UV-irradiation of the cells to reduce the synthesis of chromosomally-determined polypeptides (Sancar et al., 1979). The labelled polypeptides were analysed by SDS-PAGE (Fig. 4). Escherichia coli CSR603 clearly did not produce polypeptides corresponding to those encoded by pBR322 and the pEC plasmids. Escherichia coli CSR603(pBR322) produced the amp and tet polypeptides, as expected; E. coli CSR603(pEC1) and E. coli CSR603(pEC2) produced the amp but not the tet polypeptide because the $C$. fimi fragments in their plasmids were inserted in the tet gene at the BamHI site. Polypeptides of 51 and $53 \mathrm{kDal}$ were produced by $E$. coli CSR603(pEC1) and E. coli 


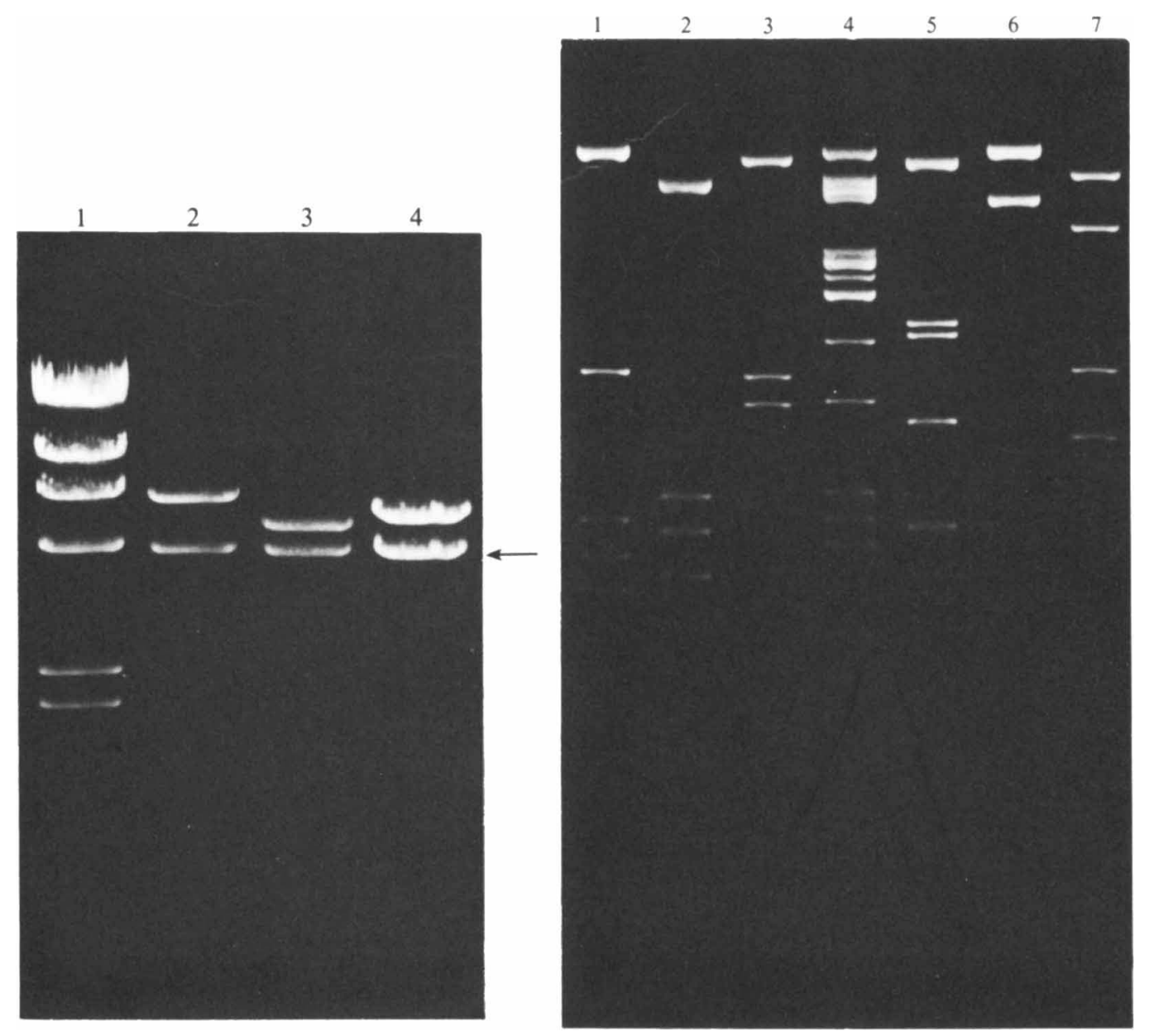

Fig. 1

Fig. 2

Fig. 1. Cloned DNA fragments coding for $C$. fimi cellulases. Plasmid DNA was isolated from $E$. coli $\mathrm{C} 600$ (pEC) strains, digested with $\mathrm{BamHI}$ and separated on a $0.7 \%$ agrose gel containing $1 \mu \mathrm{g}$ ethidium bromide $\mathrm{ml}^{-1}$. Lane 1 , HindIII-cleaved fragments of $\lambda$ phage DNA; lane $2, \mathrm{pEC} 1$; lane 3 , pEC 2 ; lane 4, pEC3. The arrow indicates linear pBR322 DNA.

Fig. 2. Restriction endonuclease digest of pEC plasmids. Purified pEC plasmids were digested with the restriction endonucleases $S a I I$ and $P$ stI. The fragments were separated on a $1 \cdot 1 \%(\mathrm{w} / \mathrm{v})$ agarose gel containing $1 \mu \mathrm{g}$ ethidium bromide $\mathrm{ml}^{-1}$. Lanes $1-3$, Sall digests of $\mathrm{pEC1}, \mathrm{pEC} 2$ and $\mathrm{pEC} 3$, respectively; lane 4, HpaI-digested T7 phage DNA as a molecular weight marker; lanes 5-7, Pst digests of $\mathrm{pEC} 1, \mathrm{pEC} 2$ and $\mathrm{pEC} 3$, respectively.

CSR603(pEC2), respectively. Neither polypeptide was produced by cells containing pBR322. The labelled polypeptides produced by cells containing $\mathrm{pEC} 1$ or $\mathrm{pEC} 2$ were analysed further by immune precipitation with antisera against the supernatants of $C$. fimi cultures grown on celluloses (Whittle et al., 1982). The antigen-antibody complexes were adsorbed on Staphylococcus aureus (Ivarie \& Jones, 1979) and the labelled proteins obtained were analysed by SDS-PAGE. Polypeptides of 51 and $53 \mathrm{kDal}$ were obtained from pEC1-containing and pEC2containing cells, respectively (Figs 5 and 6). These polypeptides corresponded closely in molecular weight to two of the cellulases in $C$. fimi culture supernatants. Thus, $\mathrm{pECl}$ and $\mathrm{pEC} 2$ encoded different components of the $C$. fimi cellulase complex. 


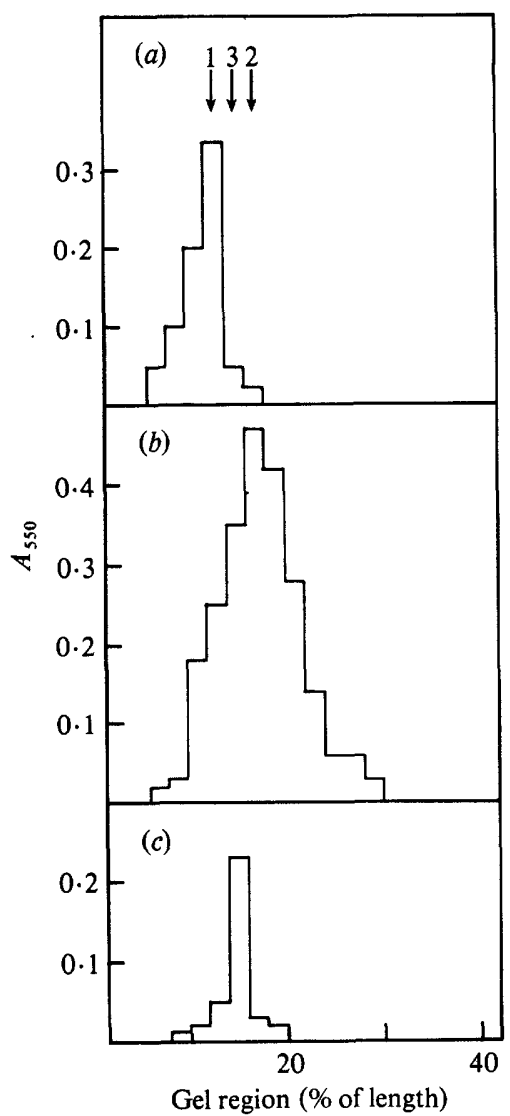

Fig. 3. PAGE analysis of cellulases encoded by pEC plasmids. Whole cell extracts of E. coli $6000(\mathrm{pEC})$ strains were run on $6 \%$ non-denaturing polyacrylamide gels. The gels were sliced in $2 \mathrm{~mm}$ fractions; these slices were placed directly into a CM-cellulase assay mixture (Langsford et al., 1984) and incubated for $18-20 \mathrm{~h}$ at $37^{\circ} \mathrm{C}$. The reactions were terminated, and reducing sugars were determined colorimetrically (Miller, 1959). (a) Activity profiles of $\mathrm{pEC1} ;(b) \mathrm{pEC} 2$; and (c) pEC3. N.B. Only the top part of the gel is shown here; since no activity was seen in the remainder of the gel, the top part is plotted in an expanded form. The arrows in (a) show the relative positions of the three activities.

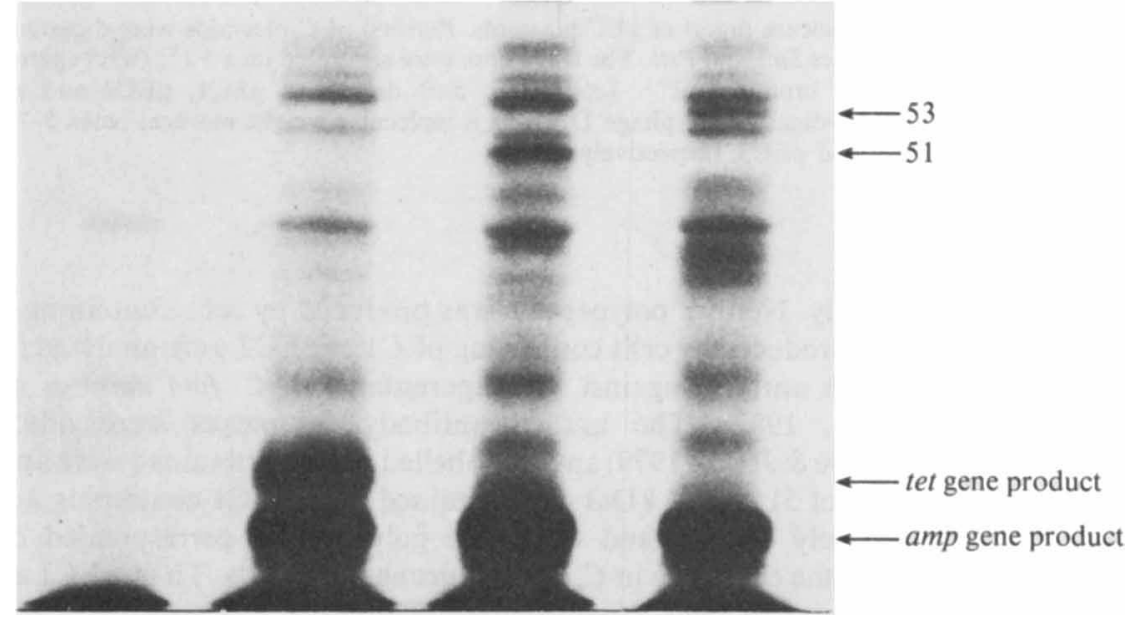




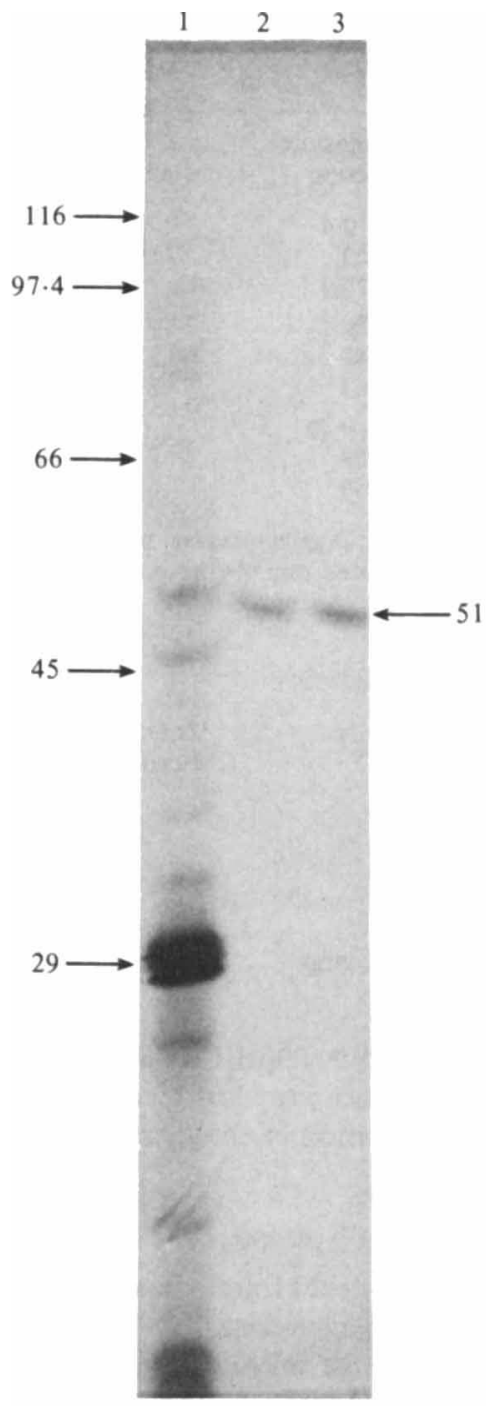

Fig. 5

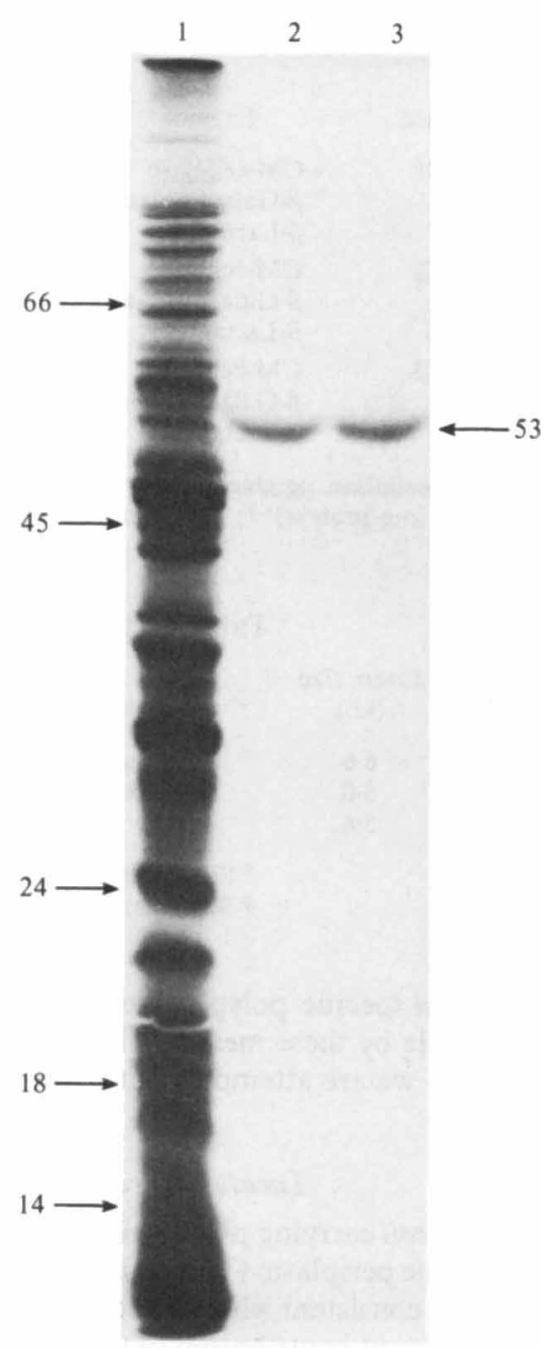

Fig. 6

Fig. 5. Immunoprecipitation of $\mathrm{pECl}$ polypeptide. The proteins encoded by $\mathrm{pECl}$ were labelled as described in Fig. 4. The labelled proteins then were precipitated with various antisera, and the precipitates were analysed by SDS-PAGE. Lane 1, the labelled proteins before treatment with antisera; lane 2, protein precipitated with antisera raised against CM-cellulose-induced $C$. fimi extracellular enzymes; lane 3, protein precipitated by antisera raised against Avicel-induced $C$. fimi extracellular enzyme. Numbers refer to sizes (kDal).

Fig. 6. Immunoprecipitation of $\mathrm{pEC} 2$ polypeptide. The proteins encoded by $\mathrm{pEC} 2$ were labelled as described in Fig. 4. The labelled proteins then were precipitated with various antisera, and the precipitates analysed by SDS-PAGE. Lane 1, the labelled proteins before treatment with antisera; lane 2, protein precipitated with a monoclonal antibody, A2/23.11.32 (Langsford et al., 1984) directed against $C$. fimi cellulase; lane 3, protein precipitated with antisera raised against $C M$-cellulose-induced C. fimi extracellular enzymes. Numbers refer to sizes (kDal).

Fig. 4. Polypeptides encoded by cloned DNA fragments. Strain CSR603 was transformed with plasmids $\mathrm{pEC} 1$ and $\mathrm{pEC} 2$. The proteins encoded by the plasmids were labelled according to the procedures of Sancar et al. (1979). The labelled proteins were analysed by SDS-PAGE. Lane 1, CSR603; lane 2, CSR603(pBR322); lane 3, CSR603(pEC1); lane 4, CSR603(pEC2). Numbers refer to sizes (kDal). 
Table 1. Specific activities of CM-cellulase and marker enzymes in E. coli( $(p E C)$ strains

\begin{tabular}{clccc}
\multirow{2}{*}{ Plasmid } & \multicolumn{3}{c}{ Specific activity* in: } \\
\cline { 3 - 5 } pEC1 & $\overbrace{\begin{array}{c}\text { Periplasmic } \\
\text { fraction }\end{array}}$ & $\begin{array}{c}\text { Cytoplasmic } \\
\text { fraction }\end{array}$ & Cell extract \\
& $\begin{array}{c}\text { CM-cellulase } \\
\text { pEC2 }\end{array}$ & 26 & 0.4 & $3 \cdot 6$ \\
& $\beta$-Galactosidase & 160 & 2722 & 1932 \\
& CM-celluase & 14480 & $72 \cdot 9$ & 2200 \\
& $\beta$-Galactosidase & 95 & 29 & 39 \\
pEC3 & $\beta$-Lactamase & 9372 & 4048 & 2738 \\
& CM-cellulase & $10 \cdot 3$ & 63 & 2604 \\
& $\beta$-Galactosidase & 584 & $0 \cdot 36$ & $1 \cdot 2$ \\
& $\beta$-Lactamase & 67653 & 4909 & 2892 \\
& & & 2556 & 6390
\end{tabular}

* Units: CM-cellulase, $\mu \mathrm{g}$ glucose equiv. released $\min ^{-1}(\mathrm{mg} \text { protein })^{-1} ; \beta$-galactosidase, nmol $o$-nitrophenol released $\min ^{-1}(\mathrm{mg} \text { protein })^{-1} ; \beta$-lactamase, nmol nitrocefoic acid produced $\min ^{-1}(\mathrm{mg} \text { protein })^{-1}$.

Table 2. Characteristics of cellulase plasmids

$\begin{array}{ccccc}\text { Plasmid } & \begin{array}{c}\text { Insert size } \\ (\mathbf{k b})\end{array} & \text { Antigenicity } & \begin{array}{c}\text { CM-cellulase activity } \\ \text { in E. coli* }\end{array} & \begin{array}{c}\text { Zone of clearing on } \\ \text { CM-cellulose-Congo red } \dagger\end{array} \\ \text { pEC1 } & 6.6 & \text { Strong } & 3.6 & - \\ \text { pEC2 } & 5.0 & \text { Weak } & 39 & ++ \\ \text { pEC3 } & 5.6 & \text { Very weak } & 1.2 & + \\ & & \text { * See Table 1 for units of activity. } \\ & \text { † Symbols: }- \text {, absent; +, moderate; + +, large. }\end{array}$

The C. fimi-specific polypeptides(s) produced by E. coli CSR603(pEC3) were not clearly distinguishable by these methods. It seems that the cells produce very low levels of this polypeptide(s), so we are attempting to increase the level of expression of the gene(s) to facilitate identification.

\section{Location of cellulase activity in $E$. coli $(p E C)$ strains}

Cells of $E$. coli carrying pEC1, pEC2 or pEC3 exported significant fractions of their cellulase activities to the periplasm (Table 1). The very low levels of $\beta$-galactosidase from the periplasmic fraction were consistent with its known cytoplasmic location in the cell and indicated that there was no significant contribution of cytoplasmic enzymes to the activities measured in the periplasmic fraction. Very low levels of cellulase activity were found in $E$. coli(pEC) supernatants, and these probably arose as a result of cell lysis (data not shown).

Colonies of $E$. coli(pEC2) or E. coli(pEC3) produced haloes on CM-cellulose plates, whereas $E$. coli $(\mathrm{pEC} 1)$ did not produce haloes on these plates even though its CM-cellulase activity was higher than that of E. coli(pEC3) (Table 2). In our hands this procedure worked best and most reproducibly if the colonies were washed from the agar surface before the plates were flooded with the Congo red solution. Clearly, the enzymic activity of $\mathrm{pEC} 1$ was qualitatively different from those of $\mathrm{pEC} 2$ and $\mathrm{pEC} 3$. Similar results were obtained using a leaky strain of $E$. coli which released the enzymes into the culture medium. The isolation and characterization of this mutant are described elsewhere (Gilkes et al., 1984).

\section{DISCUSSION}

The $C$. fimi cellulase system contains three or maybe four enzymically active components (Langsford et al., 1984). The newly isolated plasmids described in this paper account for three of these components. The properties of these plasmids, together with the characteristics they confer on $E$. coli, are summarized in Table 2 . The restriction enzyme analysis shows clearly that 
the three plasmids are different as are the antigenic and enzymic properties of the cellulases they encode. The mobilities of these cellulases on native polyacrylamide gels are similar and the $C$. fimi polypeptides encoded by $\mathrm{pEC} 1$ and $\mathrm{pEC} 2$ are of similar molecular weight. Their electrophoretic mobilities are similar to but not identical with those of the major $C$. fimi cellulases. Since it is likely that the $E$. coli enzymes are not glycosylated whereas at least two of the $C$. fimi cellulases are, slight differences in mobility are to be expected.

The production of haloes on CM-cellulose plates by colonies of $E$. coli(pEC2) and $E$. coli(pEC3) allows direct selection of cellulase-producing clones and has been used successfully to select sub-clones of pEC2 (unpublished results). However, we still favour the use of the immunoassay because it detects clones with $\mathrm{CM}$-cellulase activities which do not produce haloes on CMcellulose plates. It will also detect components without CM-cellulase activity which could act synergistically with the active components present in $C$. fimi supernatants.

Halo formation on CM-cellulose plates results from cleavage of CM-cellulose into fragments smaller than cellohexaose to which Congo red does not bind (Wood, 1980). In addition, haloes could result from cleavage of CM-cellulose into fragments small enough to be washed out of the plates during the staining procedure. In either case, only endoglucanase activity would be expected to produce a zone of clearing. Consequently, the CM-cellulase activity encoded by $E$. coli $(\mathrm{pECl})$, which does not produce haloes on CM-cellulose plates, may be an exoglucanase. Exoglucanase would still generate new reducing groups detectable by the reducing sugar assay. Conversely, the pEC3 enzyme could be an endoglucanase which would cleave CM-cellulose infrequently. This would give low activity by the reducing sugar assay, but produce haloes on a CM-cellulose plate.

The CM-cellulase activities of the individual E. coli(pEC) strains are low compared to the activity of a C. fimi culture supernatant. However, it must be borne in mind that the supernatant contains multiple component(s) of the cellulase system, which probably act synergistically, whereas the $E$. coli strains produce only single components of the system. Cloning of the remaining component(s) will allow reconstitution of the system and elucidation of the synergism between the various products of the cloned genes.

This research was supported by Strategic Grant 67-0941 from the Natural Sciences and Engineering Research Council of Canada to D.G.K., R.C.M. and R.A.J.W. We would like to thank Valerie Raffle for excellent technical assistance.

\section{REFERENCES}

Dunn, R., Delaney, A. D., Gillam, I. C., Hayashi, S., Tener, G. M., Grigliatti, T., MisRa, V., SpurR, M. G., TAYloR, D. M. \& Miller, R. C., JR (1979). Isolation of recombinant DNA plasmids carrying Drosophila tRNA genes. Gene 7, 197-215.

Gilkes, N. R., KilbuRN, D. G., MilleR, R. C., JR \& WARREN, R. A. J. (1984). Isolation of a mutant of Escherichia coli which leaks cellulase activity encoded by cloned cellulase genes from Cellulomonas fimi. Bio/Technology 2, 259-263.

IVARIE, R. D. \& JonES, P. P. (1979). A rapid, sensitive assay for specific protein synthesis in cells and cellfree translation: use of Staphylococcus aureus as an adsorbant for immune complexes. Analytical Biochemistry 97, 24-35.

LANGSFORD, M. L., GILKES, N. R., WaKaRchUK, W. W., KilburN, D. G., MilleR, R. C., JR \& WARREN, R. A. J. (1984). The cellulase system of Cellulomonas fimi. Journal of General Microbiology 130, 1367-1376.

Maniatis, T., Fritsch E. F. \& Sambrook, J. (1982) Molecular Cloning: a Laboratory Manual. Cold
Spring Harbor, New York: Cold Spring Harbor Laboratory.

MilleR, G. L. (1959). Use of dinitrosalicylic reagent for determination of reducing sugars. Analytical Chemistry 31, 426-428.

Miller, G. L., Blum, R., Glennon, W. E. \& Burton, A. L. (1960). Measurement of carboxymethylcellulase activity. Analytical Biochemistry 2, 127132.

Miller, J. H. (1972). Experiments in Molecular Genetics. Cold Spring Harbor, New York: Cold Spring Harbor Laboratory.

NeU, H. C. \& Heppel, L. A. (1965). The release of enzymes from Escherichia coli by osmotic shock and during the formation of spheroplasts. Journal of Biological Chemistry 240, 3685-3692.

Nossal, N. G. \& HePpel, L. A. (1966). The release of enzymes by osmotic shock from Escherichia coli in exponential phase. Journal of Biological Chemistry 241, 3055-3062.

O'Callaghan, C. H., Morris, A., Kirby, S. M. \& SHINGLER, A. H. (1972). Novel method for detection 
of $\beta$-lactamase by using a chromogenic cephalosporin substrate. Antimicrobial Agents and Chemotherapy 1, 283-288.

SANCAR, A., HACK, A. \& RUPP, W. D. (1979). A simple method for identification of plasmid coded proteins. Journal of Bacteriology 137, 692-693.

Teather, R. M. \& Wood, P. J. (1982). Use of Congo red-polysaccharide interactions in enumeration and characterization of cellulolytic bacteria from bovine rumen. Applied and Environmental Microbiology 43, 777-780.

Whittle, D. J., Kilburn, D. G., Warren, R. A. J. \& MilleR, R. C., JR (1982). Molecular cloning of a Cellulomonas fimi cellulase gene in Escherichia coli. Gene 17, 139-145.

WoOD, P. J. (1980). Specificity in the interaction of direct dyes with polysaccharides. Carbohydrate $R e^{-}$ search 85, 271-287. 